\title{
5 Youths' and their guardians' prospects of reindeer husbandry in Finland
}

\author{
Tanja Joona and Pigga Keskitalo
}

\section{Introduction}

This chapter investigates what young reindeer herders think about their livelihood and future prospects to continue in this profession in Finnish reindeer herding districts. In addition, their guardians are interviewed so that the overall family perspective is available. Reindeer herding is a traditional livelihood practised across the Arctic and Subarctic regions, areas that have become the intense focus of development and policy interests. The Arctic area is predicted to experience dramatic climate shifts over the coming decades as a result of climate change. Young reindeer herders today face an uncertain future. Reindeer herders' pastures are being lost, and the full range of the consequences and impact of climate change is unclear. The conditions under which they practise herding today may be very different by the time they reach middle age. It is crucial for the future of reindeer husbandry that the youth adopt positive thinking, know how to assess opportunities and reach out to the future. The youths' choices are important when it comes to the future of reindeer herding - whether or not they decide to become reindeer herders.

The study cases are in the following selected areas of reindeer herding cooperatives: Palojärvi in the town of Ylitornio (South-West of Lapland), Kaldooaivi in the municipality of Utsjoki (North of Lapland) and Näkkälä in the municipality of Enontekiö (North of Lapland) (see Reindeer Herders' Association 2020a, p. 11). According to previous studies, reindeer herding is being affected by the pressure of competing land use (Pogodaev and Oskal 2015), climate change impact (Vuojala-Magga et al. 2011; Box et al. 2019) and fear of an unstable future (Kaiser 2011; Omma et al. 2011; Kaiser et al. 2013, 2010). Mirroring a great deal of external stressors (Arctic Council Sustainable Development Working Group [SDWG] 2015), it is imperative to understand the rapid changes in the Arctic and ways to improve adaptation practices, what kind of views the youth hold and what kind of ideas they have with regard to the future of the reindeer herding and whether young people are willing to continue the livelihood. This chapter increases the knowledge on the future prospects of young reindeer herders in Finland. The knowledge can be used when developing the conditions of young 
herders as well as the northern communities as a whole. Instead of following the global trend of immigration to cities, Indigenous communities can stay viable with strong cultural ties to traditional lands and natural resources (United Nations 2009, p. 93).

Reindeer herding as it exists today began in the late Middle Ages. The Sámi started herding reindeer and migrated nomadically with their herds according to the rhythm of the seasons. The Finnish population also adopted reindeer herding early on and developed it further for their own needs. Reindeer husbandry considers the characteristics of each area, such as the terrain, settlements and natural conditions (Reindeer Herders' Association 2020a, p. 17).

Finnish Lapland covers about a third $\left(100,369 \mathrm{~km}^{2}\right)$ of Finland's total area. It is sparsely populated, the density being just two inhabitants per square kilometre, and the total population is 179,000 inhabitants. The area is known for its peculiar landscape, wilderness and traditional livelihoods, especially reindeer herding, which is an important part of the local economy. Due to the increase in the global prices of energy and raw materials, especially minerals, a rapidly expanding invasion of industrial land use and exploitation of natural resources is occurring in Lapland. Reindeer and people have a connection that is thousands of years old, first through deer hunting, then through reindeer domestication and herding. The profession of a reindeer herder is based on information and traditions that have been passed down through generations. In their work, nature and the eight seasons of the year are always present. Pure nature is very important for the continuity of herding work and reindeer herding culture. Both women and men can be reindeer herders (Reindeer Herders' Association 2020b). However, the position of women reindeer herders can be paradoxical because of changes in society, for example desire to get education and demands of traditional society (Kaiser et al. 2015).

Many of the older generations of reindeer herders remember the days when there were expansive grazing lands (Vuojala-Magga and Turunen 2015), the predator stock was kept under reasonable control (Wennstedt 2002; Tveraa et al. 2013), the reindeer herd was dense and the whole village gathered at the fences - both reindeer and the rest of the village and nearby villages (Heikkinen 2006). However, there are very viable communities still today (Pekkarinen 2006; Sarkki et al. 2016; Lépy et al. 2018). It is clear that the standard of living in Finland has increased over the generations. Finland has progressed from one of the poorest corners of Europe in the late nineteenth century to a highly advanced and innovative industrial country ranked by assorted international indices as the happiest, most stable, safest and bestgoverned country in the world (Reiter and Lutz 2019, p. 2; Statistics Finland 2019; Voutilainen 2016). According to Kokkinen (2012), considerable input into education has had a significant relation with the dramatically changed economic performance in Finland. The Finnish economy has experienced remarkable growth over the last 150 years, as far as statistics are available. According to Ojala et al. (2006), Finland was a fully agrarian economy that was heavily regulated and reliant on foreign trade. Even as late as the 
outbreak of the Second World War, the majority of the Finnish population was still employed in agriculture. It was only during the latter part of the twentieth century that Finland became a highly versatile economy, with both industries and services blossoming simultaneously. This progress was accompanied by the development of an extensive welfare state, high levels of investment in education and a considerable population shift from the countryside to the growing cities of southern Finland (Ojala et al. 2006; Reiter and Lutz 2019 , p. 4). These societal and economic changes have also affected reindeer husbandry. In spite of Finland being one of the wealthiest countries in the world, Indigenous peoples' rights to lands and waters are still not recognized, which complicates land usage issues related to reindeer husbandry. Getting stuck in the past means paralysis in reindeer herding if only the past is seen as positive (Reinert et al. 2009). If instead of looking for opportunities and the positive impact of today's reindeer herding and future prospects we become paralysed by the fear of change, the world begins to look hopeless, and the future runs its course negatively affecting children and young people. When the world begins to look hopeless, young people often tend to seek something else. Reindeer husbandry-if nothing else - provides an excellent starting point for those willing to work as an entrepreneur and professional reindeer herder. The work is independent, close to the traditional living style of the local culture and conducted outside with animals. However, there are also many challenges - the profession is prone to accidents and vulnerable to the disadvantages of other forms of land use. Fortunately, the reindeer herder entrepreneurship field has been able to build on positive premises rather than negative - the share of reindeer owners under the age of 25 is higher than the share of retired people. Of course, traditionally, people of all ages play a valuable role in the practical work of reindeer herding. Children grow up to care for reindeer from their infancy, and the elderly participate in the work for as long as their health allows. The work is done together, taking turns caring for the others. Reindeer husbandry bridges generational gaps (Ollila 2019, 2014).

In Finland, there are around 900 reindeer owners under the age of 25, located in every part of the broad reindeer husbandry area from north Finland to the southern areas of the reindeer herding region (see Figure 5.1), and they are actively involved in reindeer herding. There are girls and boys of every age from the north, centre and south of the reindeer herding district (Jernsletten and Klokov 2002; Reindeer Herders' Association 2020c). The willingness of young reindeer herders to continue herding is obviously the principal element for continuity. The good news is that there are young people interested in becoming reindeer herders. Only the southern reindeer husbandry area is experiencing problems with this, mainly due to long-term problems with large carnivores (Reindeer Herders' Association 2020c).

Many youngsters make a very important decision for the future of reindeer herding - they decide to become reindeer herders. Every year, several dozen youths decide to take a reindeer husbandry entrepreneurship education at the Sámi Education Institute in Inari, Finland, to qualify for start-up aid in the 


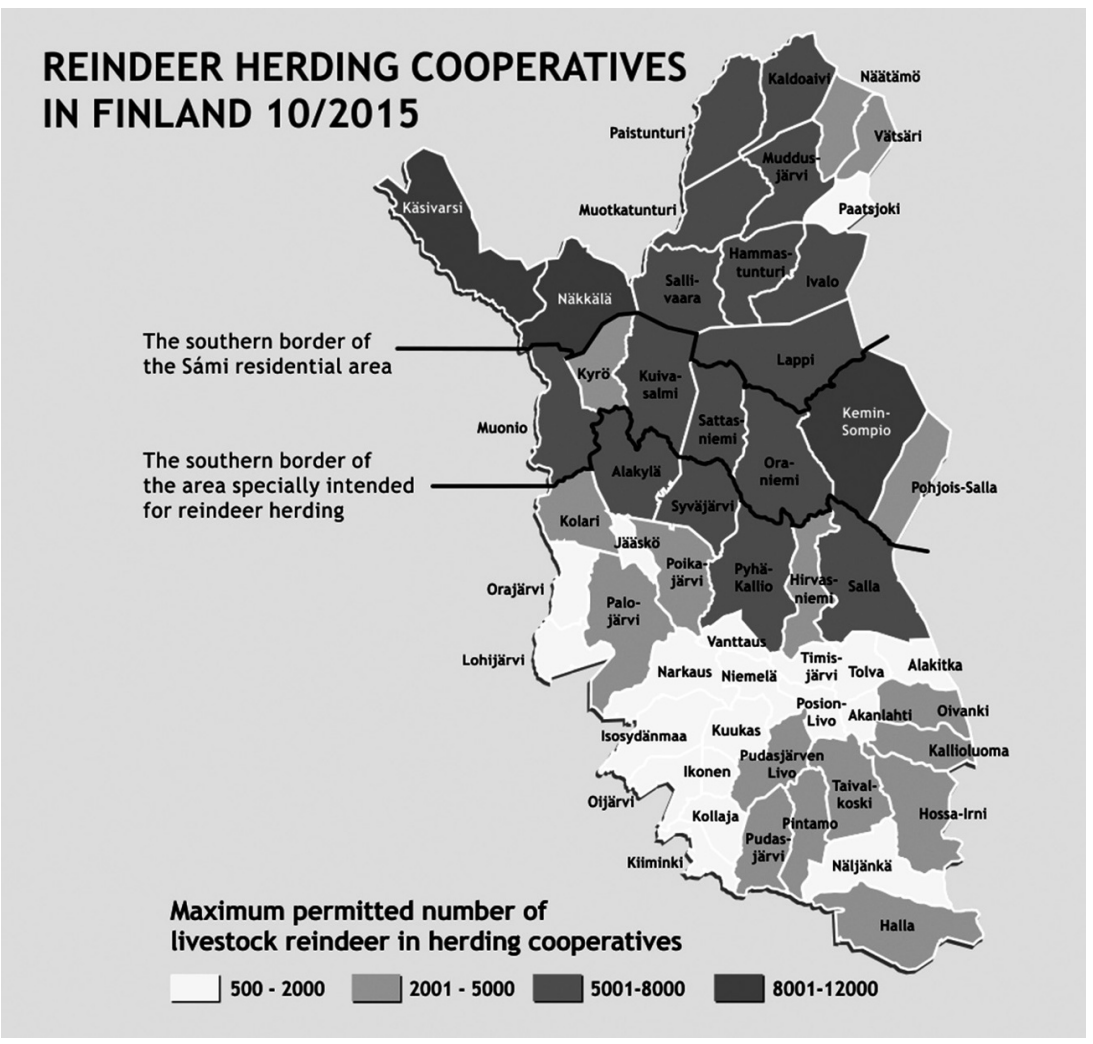

Figure 5.1 Reindeer Herding Districts in Finland and the numbers of reindeer.

(Source: Reindeer Herders' Association 2015)

profession (Sámi Education Institute 2020). The institute not only teaches how to become a professional reindeer herder; it also teaches how to utilize reindeer meat and skin, how to make handicrafts and clothes from reindeer horns and leather, for example. It is expected that to be able to work as a professional reindeer herder with economical support, one needs education in the reindeer herding entrepreneur profession and needs to have a minimum requirement of 80 living reindeer. In Finland, reindeer herding can be studied as a vocational education at the Sámi Education Institute Toivoniemi campus in Kaamanen, a village 30 kilometres north of Inari within the precincts of suitable buildings and structures. There are three kinds of study options. The first is a full basic study programme that consists of two to three years of study conducted on the campus and reindeer herding farms. The second programme is learning to work as part of an apprenticeship training and is conducted mainly at their own family reindeer herd or related places. Students go to campus to study and meet the teachers, and then they do their skills demonstration. The third option is open vocational education training that gives study credits (Frangou and Keskitalo 2020; Keskitalo et al. 2020). 
The lives of young reindeer herders are governed differently than in the days before the societal changes, changes in profession, technical development and aspects affecting the profession (Reindeer Herders' Association 2020b). Times change, and life changes with it. Livelihoods and cultures, including reindeer husbandry, are also changing, and reindeer herders adapt with the changes (Rasmus et al. 2016).

We consider people under 29 years of age young reindeer herders, according to Finland's Youth Act, which defines youth to be those under 29 (Nuorisolaki 1285/2016). In the opinion of young people, the definition in the Youth Act is too broad. According to the young people themselves, youth begins at around the age of 10 and ends around 20 (Merikivi, Myllyniemi and Salasuo 2016).

The interviews aim to answer the overall research question of the youth's connectedness to reindeer herding. The sub-questions are as follows:

1. What are the first memories of reindeer herding in the youths' lives?

2. How is the family occupied in the reindeer herding livelihood?

3. What prospects do the youths perceive in future reindeer herding?

The aim of the research question is to discover the overall ideas that the youth have about reindeer herding through their narratives and their prospects in the future to open their minds to future ideas about their career choices. We have asked questions to illuminate the youth's connectedness to reindeer herding. ${ }^{2}$ The thematic interview contained background questions concerning the ages and genders of the interviewees $(\mathrm{N}=12)$. The interviews were semi-structured, and a data-driven content analysis was performed (Anderson 2004).

\section{Studies about Indigenous youths' prospects in the Artic context}

This chapter is interested in processing the ideas of young reindeer herders and their guardians about the entrepreneur in the Arctic context in Finland. In the literature review, we looked at what other researchers have stated about reindeer herding as a profession and, more specifically, what the youth think according to previous studies about the profession to explain future prospects.

Most remote communities in the Arctic share their fate with Europe's northern periphery in that demographic development is characterized by a population decline that has been going on for decades (Karlsdottir and Jungsberg 2015). According to recent and former studies (e.g. Heleniak 2020; Nymand Larsen et al. 2010), it is often difficult to get skilled young people that have moved away because of studies, work and other reasons to come back to their home regions to help create growth and optimism. One explanation for this problem is that there is no variety of jobs or education possibilities (Keskitalo 2019). In many cases, there is also a lack of women because of limited job opportunities and because they consider the opportunities for personal expression and recognition insufficient. Many young people across 
the Arctic region imagine themselves holding secure, well-paid jobs in the future, and they see education as one way to achieve this. Some young students from the Faroese Islands argue that future education will be even more ambitious than it is today if they are to catch up with technological developments in the next 20 years or so. Students are even ready to do extracurricular activities for this reason. The idea that future young people have to learn much more than today indicates that learning is seen as a means of societal development (Karlsdottìr and Jungsberg 2015). Reindeer husbandry, however, kept villages populated, so it had a strong regional impact (Luke 2016).

When looking at the mobility of young people, living in the countryside can be seen as a choice in terms of the development of urbanization - and for a growing number of people, a wider lifestyle choice. The questions are: who stays, and who leaves? For those families who have stayed, the adults had to make a choice. Young people choose what to do after primary school, where to go to study their vocational education and then what to do after. The people living in the countryside do not necessarily expect urban services, but the place of residence is chosen according to what is considered important in life. The constant striving for material gain has been questioned. The significance of leisure time, human relationships and physical exercise in contributing to people's happiness addresses questions of the extent to which the countryside has a kind of 'wellbeing surplus' in the minds of the young (Nieminen-Sundell 2011). The findings are blended. Youth are at a stage in their lives where they want to travel, and many of them will not settle as established grown-ups for 10 to 15 years. In many ways, the youth period in life has become extended with increased formal requirements on training and education until one enters life as a fully acknowledged adult citizen (Evans, 2018). This state of transience is in many ways liberating, but it can also feel troubling. Looking at the youth from the Arctic regions, they are attracted to more urban settlements in the short term, whereas in the 20-25-year perspective, it could be interesting to live in the area of their upbringing. One dominating trend is how the youth's lifestyle is, to a large extent, connected to an urban settlement. Therefore, it is difficult for the youth to 'realize' themselves as young people staying in a rural area in the short term. This is also reflected in their ambitions of being mobile to pursue education and work (Jones 2002; Hoolachan et al. 2017). Similarities can be found all over the Arctic.

According to Kaiser et al. (2013), the experience of the young reindeer herders was that being a reindeer herder is a privileged position which also implies many impossibilities and unjust adversities they have no control over and that there is nothing they can do but 'bite the bullet' or be a failure. The Eallin - the reindeer-herding youth project conducted by the Arctic Council SDWG (2015) - gives good examples of how the future of reindeer herding is seen by Sámi youth from Fennoscandia, Nenets and Khanty in the YamalNenets Autonomous Okrug; Dolgan, Chukchi, Yukagir, Even and Evenki in the Republic of Sakha (Yakutia), Russia; Evenki from China; and the herding youth from Mongolia. To sum up, the Eallin project showed that the youth are greatly concerned about the loss of grazing land. The loss and disturbance of 
reindeer pastures are primarily related to mining, windmill extraction and infrastructure development. Predators and protected areas are also major concerns. Encroachments have had a large impact on reindeer husbandry in many places; thus, the reindeer-herding youth are worried that this could be a considerable threat to their future (International Centre of Reindeer Herding 2015; Uboni et al. 2016). Gradual encroachment combined with climate change is challenging the traditional livelihood of herders. Reindeer herders wish to be heard at an earlier stage in the planning processes of industry as well as contribute knowledge with regard to changes that will impact their livelihoods (International Centre of Reindeer Herding 2015).

One of the consequences of climate change, globalization and changes in lifestyle is the emergence of a situation where more females consider migrating permanently away from their home community and region, and, indeed, increasing numbers of young women actually do so. Of course, gender-based differences in migration choice are nothing new in the Arctic. In connection with large-scale resource development projects, young and middle-aged males in search of employment and income opportunities have chosen to become migrant workers, leaving their communities for either a shorter or a longer period of time in the process. Seldom have they left the community permanently. Only if the job turned out to be more permanent in character and generated substantial income have they done so. In such cases, they often arrange with their families to follow them and settle in the new town or village. Females, however, seem to migrate more permanently. Moreover, such choices have significant implications for the communities they leave, for instance, decreasing opportunities for marriage and the maintenance of family life and family structures as well as fundamentally influencing other cultural activities (Rasmussen 2009). The gender-related perception of customary male activities related to resource exploitation seems to be 'sticky' in the sense that males have difficulty in moving on from what once were key activities but now constitute only a small percentage of the available jobs. Females, however, seem less limited by specific job characteristics, determined by what may be considered 'traditional' and 'acceptable' activities.

Another interesting study on Nordic Arctic youth and their future perspectives in connection with the project Foresight Analysis for Sustainable Regional Development in the Nordic Arctic was commissioned by the Nordic Working Group for Sustainable Regional Development in the Arctic (Karlsdottir 2015; Karlsdottìr and Jungsberg 2015). The study investigates social sustainability involving questions about attracting and/or keeping young people, especially women, in peripheral communities. This is a fundamental issue in keeping these communities viable, inhabited and attractive for everybody. The study involved several topics in which we are especially interestedculture and Indigenous traditions as well as the impact of social media on youth. The study shows how social media platforms can be used for empowerment purposes in policy issues concerning land use. Social media also provides connections to non-Sámi youth who are supporting the work of ensuring Sámi people acquire rights and recognition. This also indicates how 
young Sámi today are a mixed group where cooperation is less about ethnicity and instead based on shared values and future visions (Karlsdottir 2015; Karlsdottìr and Jungsberg 2015; Laitala and Puuronen 2015; Öhman 2015).

Some general guidelines mark the future of their traditional livelihood, reindeer herding. One study suggests that youth should be taken into entrepreneurship in the early stages (Fleming et al. 2015). Other studies also indicate the importance of state-supported training and resourcing for Indigenous needs (Chantrill 1998; Miller 2005; Barber and Jackson 2017). Individuals need motivation and support from their family, friends and community to adapt to the work culture and successfully get and keep a job (Haley and Fisher 2014). Their early memories partly explain the connectedness and family expectations and roles. According to studies, the family has an important role in the background of the youth's expressions in addition to personal motivation, gender, friends and family background affecting the career choices of the youth (Super et al. 1996; Chen 1997; Bandura et al. 2001; Ferry 2006). For example, youth coming from agricultural backgrounds most probably also choose to work in agriculture (Fizer 2013). The place, cultural background and time shape youths' identities and career choices (Arbona 2000).

Moreover, the kinds of measures taken towards the youth in rural and Indigenous communities are of utmost importance (Indigenous Peoples Forum at IFAD 2017). The sense of cultural and social belonging seems to be explained by means of working with traditional livelihoods, which has a further impact on the employment of young people in remote, sparsely populated Arctic regions (Veijola and Strauss-Mazzullo 2018). According to the research, youths have identified and reported a shared problem of trying to be successful in the face of the sometimes contradictory demands of their Indigenous culture and those of the dominant one (Mbunda 1983; United Nations 2009; Gillan et al. 2017). For example, many young people feel confronted with a hard choice between continuing school or staying in their community if there are no further education possibilities after primary school (West et al. 2010). Research has shown that this implicates a cluster of problems, including lack of jobs in their local communities, outmigration to find employment, the unavailability of local housing, high living costs in remote rural villages and leaving their families as well as abandoning their aspirations (Ulturgasheva 2012a, 2012b, 2014, 2015; Ulturgasheva et al. 2014).

The vulnerable situation of reindeer herders and the impact of climate change may have serious consequences for trade and herders' overall way of life (Furberg et al. 2011). Reinert et al. (2009) claimed that the key to handling permanent changes successfully is that the herders themselves have sufficient degrees of freedom to act. Further, research shows that the most important strategy of reindeer herders is constant adaptation to changing conditions (Reinert et al. 2009).

According to statistics, the number of reindeer herders in Finland has shrunk over the last 20 years; the number of men decreased from 6,000 to 3,000 between 1990 and 2018, whereas the number of women has remained roughly unchanged (Figure 5.3). Reindeer herding can be different 


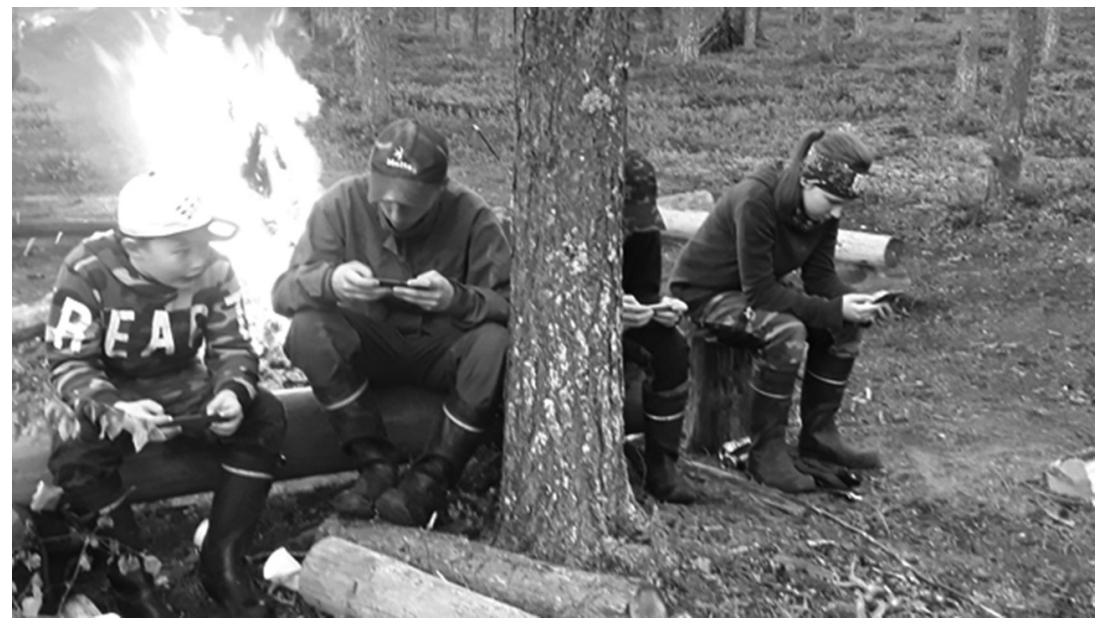

Figure 5.2 Youths during a break from summer reindeer calf marking.

(Photo: Tanja Joona)

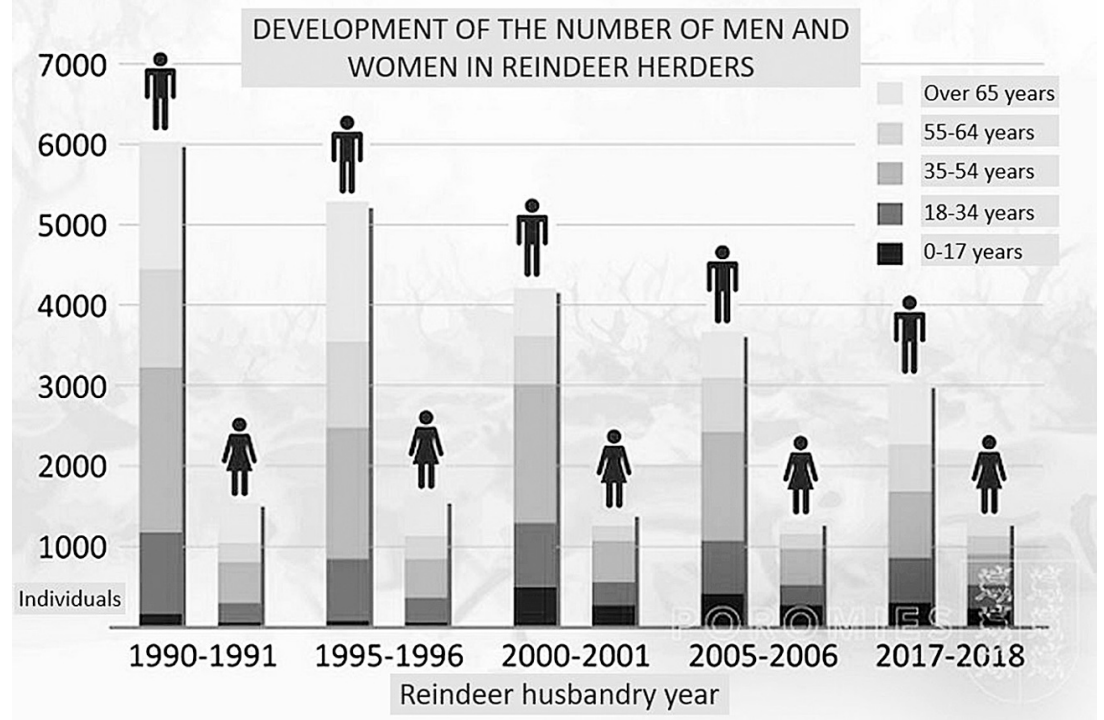

Figure 5.3 The numbers of men and women in reindeer herding, 1990-2018.

(Source: Reindeer Herders' Association 2019)

depending on the area in which one lives. Youths tend to participate in family reindeer herding work from childhood. Most youths get their reindeer mark ${ }^{3}$ when they are small, and they own reindeer in addition to everyone in their family. The living style of reindeer herding is learnt through participating in the workings of a herding and experiencing its fluctuations over time. 
Reindeer are semi-wild animals and require care for part of the year by a reindeer herder. In the northern part of Finland's reindeer herding area, reindeer graze more freely, and they require constant herding by reindeer herders. During the winter, many reindeer herders feed them even if the reindeer are not in fences because the pastures are becoming smaller depending on the area. In summer or autumn, there are reindeer markings. Some reindeer herders make hay for reindeer. Reindeer herders repair fences and maintain equipment. In autumn, there are reindeer round-ups and all the work involved both before and after that. Further, the work is carried out in various kinds of weather conditions (Joona 2018; Pirttilä 2020).

According to Rehtonen (2019), there are two sides to the development of the age structure of reindeer owners. There are increasingly more young people working as reindeer herders - especially young women. Until 2014, the upper age limit for individual aid was 65 years. However, under EU law, the restriction was considered age discrimination. As a result of the abolition of the age limit, the share of retired people, mainly men, in reindeer herders has increased by 150 since 2014. The Reindeer Herders' Association is concerned about this development since younger people cannot continue working if their parents do not give up the work. Those leaving the sector have been predominantly male, while the proportion of women has remained broadly the same throughout. Currently, there are people of all ages among reindeer owners, but this has not always been the case. The most significant change has been the entry of young women into the sector. As late as 1995-1996, reindeer owner statistics did not show any women under the age of 17, but as early as 2005-2006, there were almost as many women as men. Today, the phenomenon is reflected, for example, in the number of applicants for start-up aid for reindeer husbandry. The change is significant. It can be seen that the situation has levelled off both between generations and between the genders (Rehtonen 2019).

According to Oinas (2018), competence and management in reindeer husbandry work include tacit knowledge that has been acquired since childhood. Reindeer husbandry has several different means of survival that carry reindeer herders and their families through challenging situations. The attachment of the lifestyle identity and the historicity make reindeer herding binding on most generations and binding on itself and the community. From a community perspective, the lifestyle is in many ways a transition to weakened economic profitability and the consequent reduction in number of employees. Changes in the economic and social aspects of reindeer husbandry have had an impact on the relationships between reindeer herders in various ways in different herds. At one extreme, the spaces may have tightened and escalated, while those left at the other extreme have condensed further cooperation, and the importance and contribution of everyone involved is highlighted. The decisive factor for the future of an individual group is whether the situation of the group is such that, according to new, young generations of reindeer herders, entry into reindeer husbandry work is still sensible and possible (Oinas 2018).

According to Daerga et al. (2008), men and women from reindeer-herding families need partly different conditions to enjoy a high quality of life. From 
their results, it might be predicted that poor somatic and psychosocial health, increased intrusion from exploiters on the grazing land and declining profit in reindeer husbandry constitute important threats to a good quality of life among members of reindeer-herding families (Daerga et al. 2008). According to Buchanan et al. (2016), rural communities that rely on natural resources around the world demonstrate a highly gendered division of labour, and pastoralists such as reindeer-herding communities appear to be no exception. Young and older female and male reindeer herders reported that there are different expectations for men and women in households regarding who should support reindeer husbandry and how this should be done. Boys are frequently socialized into the profession differently than girls (Buchanan et al. 2016).

\section{The voices and views of the young herders and their guardians}

\section{Connectedness and memories about reindeer herding}

The connectedness of reindeer herding tells about sociological processes of an Indigenous traditional living style (Balto 1997). The first memories related to reindeer herding are gained in early childhood. The socialization process into the livelihood is done through the family and the living style of the family. All the interviewees have had reindeer in their families. We were interviewing those actively occupied in the profession.

The first memories are when I was three or four years old from calf marking.

(young male)

All the interviewees are from families who have been reindeer herders for generations, and the living style has been passed down from generation to generation, from grandparents to sons and their children or near kin.

When asked who is the most active in the reindeer-herding family, the answers varied. Often youths answer that it is the family's father. It seems that most of the active reindeer herders are men, according to the interviews, so the profession is often gender-tight.

Most active reindeer herder in my nuclear family is my father.

(young female)

Or sometimes the extended family:

My uncles and cousins have an active reindeer herding activity.

(young male)

Still, there are also women in the livelihood. According to Joks (2005), women serve an invisible but important part of reindeer herding, doing a lot of things that are not so obvious, for example, taking care of things at home when the men are herding in the forest or mountains. Mothers or female 
relatives also look after the young children during the actual reindeer herding works, such as calf marking in the summer or separation and slaughtering in the fall.

The home means a lot for reindeer-herding youth. An interviewee claims that there is a willingness to come back after studies, meaning that one must often move away from home to study. The youths' ideas about studying elsewhere consist of traveling and getting new insights into life:

I want to live in the same place in a home village in the future. Before that, I'm going to study elsewhere, I still don't know where. Possibly, I will also travel during these years.

(young female)

The youths consider their connectedness to their livelihood as part of their everyday life. Herding and its related activities are part of the annual rhythm still practised strongly in rural Lappish areas. It can be considered that reindeer herding is the centre of life and that all other things happen on its terms. If there are schooldays in the middle of the slaughtering season, kids usually stay at home and participate in the reindeer separation.

Nowadays, reindeer herding is a blend of traditional and modern life and technology. Reindeer herding is most often passed down in a family, but there are different ways to become a reindeer herder, such as through kin, as a family heritage or through learning the tradition in other ways. All youths need to receive an education to become professional reindeer herders and so they can raise grants. Of course, it is possible to be a reindeer herder without becoming a professional and instead engage it as a second occupation. It seems as though reindeer husbandry is a gender-tight and male-oriented occupation. Still, there are now increasing numbers of women and young girls who wish to become reindeer herders. They can practise differently according to the principles of the surroundings, sometimes taking part more actively in the work that men do or by doing different kinds of tasks in their home yards if there are children around. It is still a fact that reindeer herding is physically demanding work and prone to accidents because of the demanding context in working with animals and the demands from the natural surroundings. The youths explain that the living style with different kinds of seasonal work and living with reindeer herding in their home village is motivating. They are ready to see the profession as a part of their future life, either as a main profession or second occupation.

\section{Ideas about reindeer herding}

The youth think that reindeer herding is an important vocational branch, although there are things that might harm the living style, such as climate change. Reindeer husbandry is considered an industry that is vulnerable to the negative effects of climate change. Changing weather and snow conditions especially impact the reindeers' ability to find food (Kumpula 2012). 
Fortunately, reindeer herders have access to technologies and treatments that have already helped the reindeer herding livelihood adapt to the changing conditions. Reindeer husbandry does, however, still have several challenges to overcome in the process of adapting to climate change, but it is also a livelihood with a relatively high adaptation potential to the changes (Rasmus et al. 2020).

Climate change is a nasty thing. It is likely to affect the food intake of reindeer as we have already been able to realize.

(young male)

The social nature of reindeer herding is, in many ways, the driving force for young people. Summertime with calf markings is a learning time for young people. The different parts of a round-up enclosure become familiar for kids. Reindeer are handled in the churn (kirnu (Fin.) girdno (North Sámi)) when it is slaughter time.

Youths participate in different kinds of tasks during the reindeer-herding year. The high season of reindeer herding is the most interesting period according to one youth:

Reindeer calf marking and reindeer round-up are the most fun events during the reindeer year.

(young female)

After all, it is fun for the youth when they get to spend the nights in a gang.

From learning to like, it goes into the blood. Besides, they really help a lot. (parent of an interviewee)

The youths share a realistic picture of reindeer herding because they are socialized into it from childhood and participate in different kinds of tasks. They learn that the work is physically demanding, but many still want to wander with the herdsmen tens of kilometres during the day when the reindeer are gathered for separation and slaughtering in the fall. In the summer, the work takes place normally at night-time. For example, one 16-year-old male interviewee said he started at the age of 14 and walked 25 kilometres during his first night in the forest. The youth also find the different kinds of tasks interesting, and the high season of reindeer herding is a much-appreciated occasion. The youths' participation in entrepreneurial work is a natural part of family life. Everyone has their own role, depending on the age and task. Everything happens often with the support of the guardians.

\section{Future prospects}

There are many kinds of ideas about the future among the youth. A young primary school-aged girl claims that she is about to study another profession, but also wants to work in reindeer husbandry: 
I am planning to study a profession but also probably continue reindeer husbandry. I will go to high school after elementary school, after which I plan to study more. I don't know yet what profession I'm studying for. I plan to continue caring for reindeer alongside the work. I'm not going to start to work as a full-time reindeer herder.

(young female)

It seems that the girls are more willing to find a second occupation besides reindeer herding, which is natural as reindeer herding is a physical profession and is also male-oriented (Buchanan et al. 2016). It is also interesting that young females find reindeer herding very attractive and that they want to be involved with the profession in one way or another.Some youths think that the future of reindeer herding might be in crisis as they believe that the number of reindeer herders will be reduced further. The youths see that if reindeer husbandry is an ongoing profession in a family, the traditional living style is in good hands and also has a chance to be delivered to future generations (see also Oinas 2018).

The practice of reindeer husbandry will decrease in the future. I'm not sure. Depends on future generations. In our family, reindeer husbandry is likely to continue as there are so many of the family involved in a profession and living style.

(young male)

Many parents encourage children to continue in the reindeer-herding business, but they also highlight the importance of studying. This can be contradictory and requires balancing. It also reflects the intergenerational thinking and way of life.

After elementary school, I'm going to go to high school and after that maybe apply for a reindeer husbandry line in Inari. Currently, the enthusiasm for reindeer herding is fierce, but let's see then.

(young female)

I am kind of unsure yet. I am planning what to do. I have to go to the army first and decide then. I, in a way, want to study in Inari, but I am unsure if I need to study something else.

(young male)

The youths share contradictory ideas about reindeer herding. Youth is a period of insecurity and making choices. They are not quite sure what will happen in the future. Some of the interviewees are more dedicated to reindeer herding, while others are unsure and are planning to study something else. What is still certain is that everyone is willing to continue reindeer herding in some way, either as a main livelihood or as a second occupation paired with other earnings. What is also evident is that that each youth shares positive ideas about reindeer herding and that there is willingness to continue the 
livelihood. Alternatively, the modern way of life keeps the youths under pressure with obligations to the family and history and temptations typical for this age.

\section{Reindeer-herding identity}

Reindeer herders have a strong identity connected to practical work with reindeers. Identity forms at the early stages of childhood by learning from and imitating adults.

I believe reindeer husbandry will generate income for me in the future. I have my own reindeer mark and my own reindeer. I think reindeer husbandry is a nice job and kind of a nice hobby or living style if not a main profession. I can recommend it to others.

(young male)

Young people can already see the cultural connection with reindeer herding. It is not just a profession - it is a way of life.

Reindeer herding can also be really different depending on which area of Lapland you live in. Everyone has their own challenges and goals, and that's why there's as many ways to herd reindeer as there are reindeer herders. Overall, reindeer herding is more than just a profession. It's a lifestyle. I am lucky to have grown up in this community and way of life, as it will always be a part of me in one way or another.

(young female)

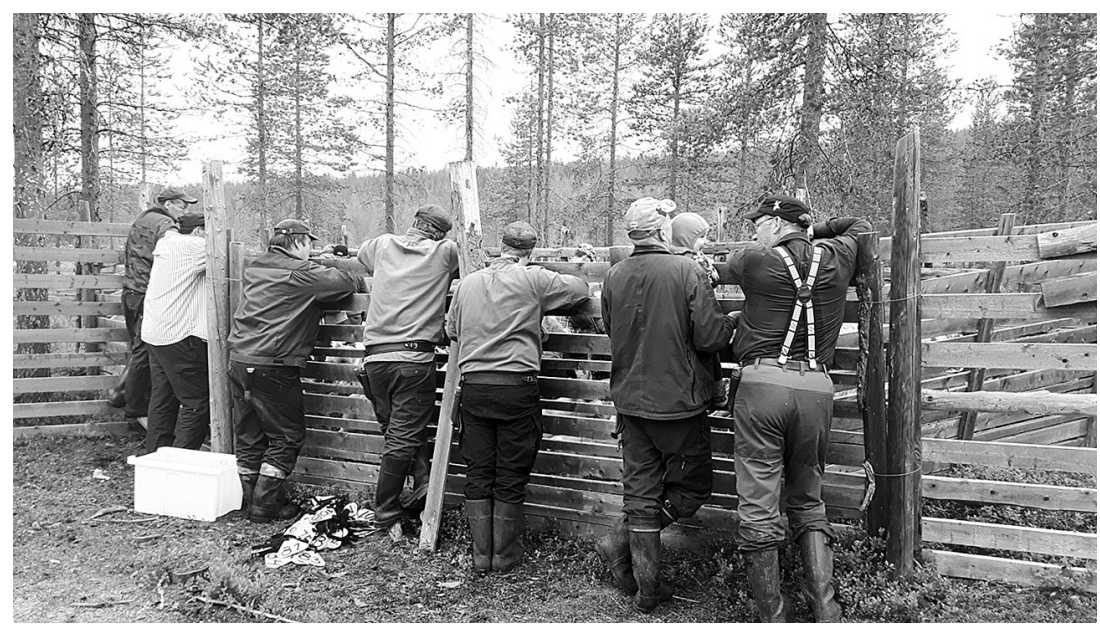

Figure 5.4 People of all ages play a valuable role in the practical work of reindeer herding.

(Photo: Tanja Joona) 


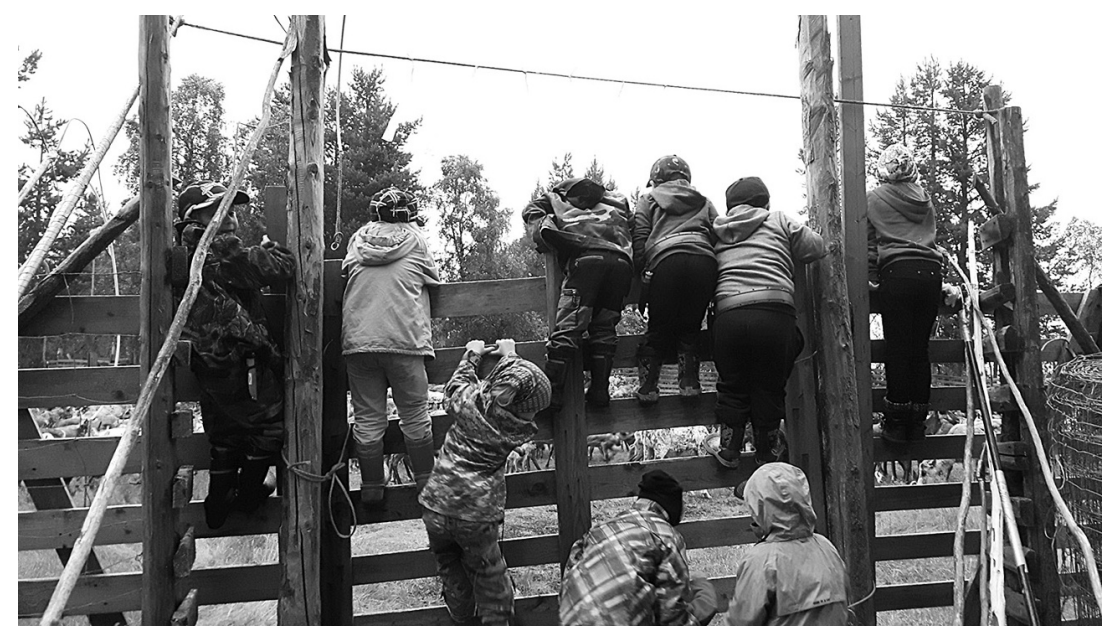

Figure 5.5 Children learn by imitating, but possess also a strong curiosity by nature. (Photo: Tanja Joona)

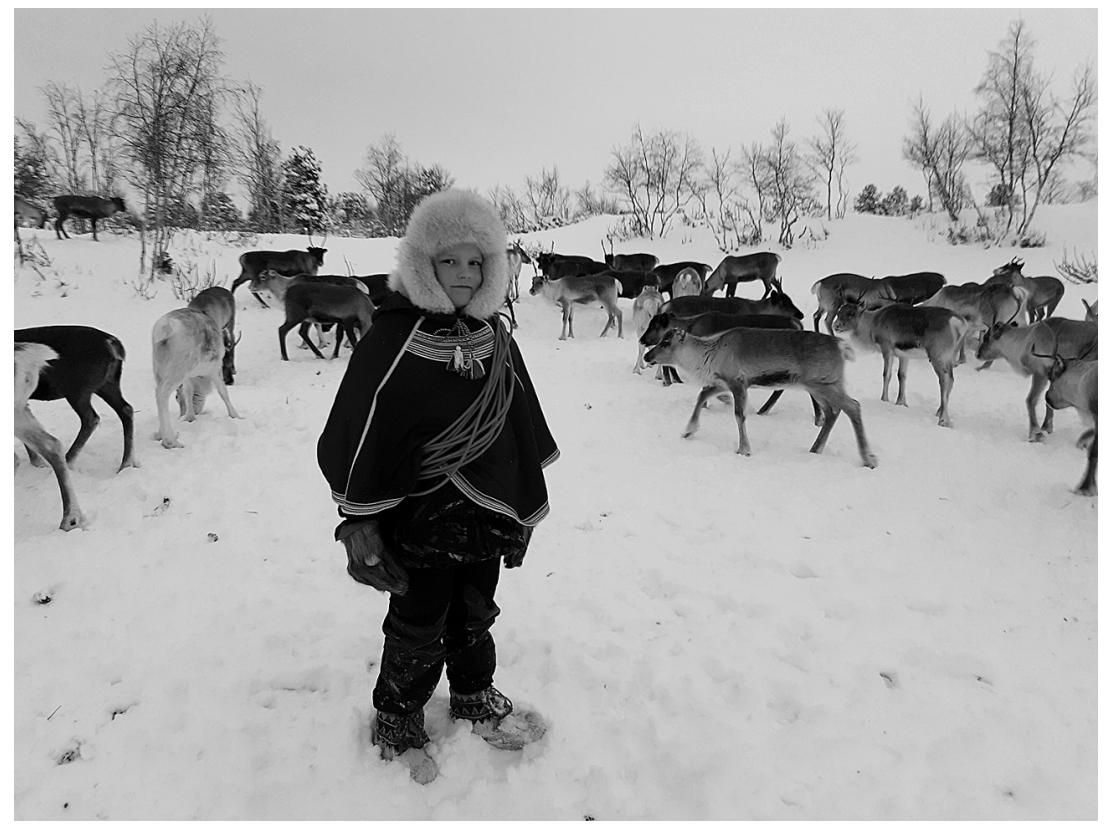

Figure 5.6 Young reindeer herder.

(Photo: Pekka Keskitalo) 
Reindeer herding has been traditionally seen as a very male-oriented occupation. This is the case in many Arctic countries. In Russia, Indigenous women and men often express their concern about an imbalanced gender relation. The increasing absence of women in the taiga and tundra is considered one of the principal reasons for the crisis in the hunting and reindeer economies (Schindler, 1997; Ssorin-Chaikov, 2003). In addition, Indigenous men, particularly in reindeer encampments, complain about the loneliness of the single life and the lack of women to share household duties (Povoroznyuk et al. 2010).

Currently in Finland, there are reindeer owners of all ages, but this has not always been the case. The most significant change has been the entry of young women into the sector. As late as 1995-1996, reindeer owner statistics did not show any women under the age of 17 , but by 2005-2006, there were almost as many women as men. Today, the phenomenon is reflected, for example, in the number of applicants for start-up aid for reindeer husbandry. According to the parents interviewed, the change is significant:

This is a big thing that has hardly been able to outline before. It can be seen that the situation has levelled off, both between generations and between the genders.

(parent of an interviewee)

It is clear that some kind of cultural change took place among reindeer herders in the early 2000s as an increasing number of girls were listed as reindeer owners. It appears that the profession has a high status, and, even for women, it is possible to study and become reindeer herders. The profession allows freedom in nature, and one can spend a lot of time outside and with animals, so the field is appealing. Reindeer herders are quite independent, and they can determine a lot by themselves and combine it with other income. Since one can study reindeer herding in a vocational education school, the profession can be seen as a real and potential profession for the youth. Still, many think that you must have some kind of connection to reindeer herding before it makes sense.

The change of ownership of reindeer is mainly between families. Maybe the mind-set has changed. One would think that the social change in gender roles is also reflected here - reindeer husbandry is not separate from the rest of the world. The debate related to gender equality has reached here as well, and it no longer matters whether the successor is a girl or a boy.

(parent of an interviewee)

The parents/guardians have a strong background position. One guardian stated that the parents support the youths in different ways but let them finally decide.

Of course, we hope that many children in a family will choose to stay in a livelihood. We try to add them to the yearly and seasonal work but they 
can decide by themselves whether they want to be more active or not. But we try to motivate them and give them a chance. I think it would be nice if youth could stay in a livelihood. But, finally, they have to choose by themselves. I think both girls and boys could be reindeer herders but I can understand as reindeer herding is a very physical profession that girls tend to educate themselves and then combine reindeer herding to the other professions or entrepreneurs. Of course, I am afraid if the youth will cope as the livelihood is quite tough. You have to have good talent and motivation to cope in a branch and you have to have a good starting point from the family, basically since childhood. I am happy to see that youth are interested in a livelihood - even in a combined form. It gives a lot of hope for the future of survival of the livelihood. I think reindeer herding has a good status nowadays and it can give a quite stable income if you work hard and plan your economy well.

(parent of an interviewee)

\section{Conclusion}

The aim of this chapter was to construct reindeer-herding youths' views about the livelihood and the future. This scholarly chapter is based on an analysis of quotes from young herders and their guardians. The picture of youth is filled with insecurity about the future, what to study and what to become later in life. In that sense, young reindeer-herding family members share a general picture of youth. Still, some are more committed to reindeer herding and secure than others. Finally, there is a shared feeling of excitement, courage and will, the base for the continuation of reindeer herding, as well as the other similar activities, including fishing, hunting and making handicrafts. The youths seem to not yet share the challenges in Finland as the male reindeer herders in Sweden (Kaiser et al. 2013). There are differences in legislation in the two countries, which pressure the reindeer herders differently. The views remain heterogeneous. In general, the views are optimistic while the different choices for life remain open. Still, all the youths saw reindeer herding as a richness and respected the contents and aspects of it.

While resource exploitation is still viewed as the main economic basis for communities in the North, the reality is that the third sector-the service sector with wage work in administration, education, social services, etc. - has become the main income source for most families. With limited job opportunities for well-educated women, however, the prospect of staying remains highly unattractive, resulting in the continuing outmigration as the only option available to them.

For many men, however, limited options exist in respect to leaving their current occupations. In the small villages of the north in particular, the situation is often desperate. Without proper qualifications, unskilled jobs become the only option, and as these are also now disappearing, the prognosis for unskilled male employment is becoming bleaker. Their incomes from traditional activities are not enough to enable them to profitably continue to work 
as these limited incomes do not enable them to re-invest in new equipment to expand their activities.

They also have difficulty finding young girls who are interested in staying in the villages, thereby severely limiting the option of generating double incomes, which are needed to maintain a life entailing traditional activities. Without skills and money, it is not possible to move to larger places to find work. This state of affairs then sees many in desperate situations accompanied by violence and abuse, which only adds to the female flight to pursue a better future and to avoid the negative consequences of the process of decline.

The villages are the first to be abandoned, though the smaller towns are now also suffering from female flight. Only the towns with higher education opportunities and a broader supply of qualified job opportunities seem to be able to maintain an environment attractive enough for younger women to enjoy. This is something very alarming and requires attention from decision-makers.

However, it is considered that the youth already in the early stages have ideas of choosing to be a professional reindeer herder, and this seems to be a gender-specific issue (Povoroznyuk et al. 2010; Vitebsky 2010). Males have stronger opinions about staying in the vocational branch of their families or kin. Even if girls decide not to have reindeer husbandry as their main profession, they still see the value of working and staying in reindeer herding meaning to have another career but also work with reindeer. Reindeer herding has strong economic and regional value as families stay in the villages because of reindeer herding. Girls are becoming more aware that they can become reindeer herders, even as a second occupation. This tension explains the change in the roles of women: young reindeer herding women stand out in a positive way. It looks like the times have changed, and women have started to see the possibilities of living in traditional livelihoods to a wider extent. After the Second World War, more people, and, in particular, women, migrated from Finland to Sweden and to bigger cities from northern villages although there were and are still women who wish to stay in the livelihood and villages.

It seems that it is possible to continue living in a traditional way. Reindeer have always been and remain the foundation of reindeer-herding peoples' lives. Reindeer provide people with shelter, food, clothing and security and are at the centre of herding peoples' universe, the foundation of their cultures, languages, worldviews and ways of knowing. Reindeer are also the foundation of the reindeer-herders' economy (Lindqvist 2009; Reinert et al. 2009).

The reindeer herders themselves are the ones caring for the future of their culture, and society should create the conditions for this. Youths are the future of reindeer-herding peoples everywhere. The option to be socialized into reindeer herding needs to be a valued thing in the primary-schoolaged youth in reindeer herding districts. School authorities and curricula need to consider reindeer-herding values and the youths in reindeer-herding families. Ideally, the local curriculum would give youths every kind of knowledge so that they can cope whether they choose to leave or stay. Local and more general knowledge is needed. More debate is needed in society 


\section{Tanja Joona and Pigga Keskitalo}

regarding northern village life and policies to support people to live their chosen way.

\section{Acknowledgements}

We sincerely thank the youths and their guardians who were interviewed for this article.

\section{Notes}

1 The first author is a researcher with decades of experience in researching Indigenous and human rights contexts. The second author similarly has decades of experience in multicultural contexts and extensive experience with educational and intercultural research. Both authors have a strong connection to reindeer husbandry as both authors are integrated in reindeer herding and are also mothers to four children.

2 See the interview questions at the end of this chapter.

3 Each reindeer owner has one's own earmark. According to the Reindeer Herders' Association (2020a), there are 21 different markings known as 'deeds' and around 12,000 earmarks currently in use.

\section{References}

Anderson, R. (2004) 'Intuitive inquiry: an epistemology of the heart for scientific inquiry', The Humanistic Psychologist, 32(4), pp. 307-341. doi: 10.1080/ 08873267.2004.9961758.

Arbona, C. (2000) 'The development of academic achievement in school aged children: precursors to career development', in Brown, S. D. and Lent, R. W. (eds.) Handbook of counseling psychology, 3rd ed. New York, NY: Wiley, pp. 270-309.

Arctic Council Sustainable Development Working Group. (2015) Youth the future of the reindeer herding peoples: Executive summary. Available at: https://oaarchive. arctic-council.org/bitstream/handle/11374/1477/SDWG_EALLINN_Doc2_ EALLINN_Executive_Summary_AC_SAO_CA04.pdf?sequence=1\&isAllowed= y (Accessed: February 18 2021).

Balto, A. (1997) Samisk barneoppdragelse i endring. Oslo: Ad Notam Gyldendal.

Bandura, A., Barbaranelli, C., Caprara, G. V. and Pastorelli, C. (2001) 'Self-efficacy beliefs as shapers of children's aspirations and career trajectories', Child Development, 72, pp. 187-206. doi: 10.1111/1467-8624.00273.

Barber, M. and Jackson, S. (2017) 'Identifying and categorizing co-benefits in statesupported Australian indigenous environmental management programs: international research implications', Ecology and Society, 22(2). Available at: http://www. jstor.org/stable/26270133 (Accessed: February 19 2021).

Box, J. E., Colgan, W. T., Christensen, T. R., Schmidt, N. M., Lund, M., Parmentier, F. J. W., ... \& Olsen, M. S. (2019). Key indicators of Arctic climate change: 19712017. Environmental Research Letters, 14(4), 045010.

Buchanan, A., Reed, M. G. and Lidestav, G. (2016) 'What's counted as a reindeer herder?Gender and the adaptive capacity of Sami reindeer herding communities in Sweden', Ambio, 45, pp. 352-362. doi: 10.1007/s13280-016-0834-1. 
Chantrill, P. (1998) 'Community justice in Indigenous communities in Queensland: prospects for keeping young people out of detention', Australian Indigenous Law Reporter, 3(2). Available at: https://heinonline.org/HOL/LandingPage?handle=hein. journals/austindlr3\&div=20\&id=\&page (Accessed: Feb 19 2021).

Chen, C. P. (1997) 'Career projection: narrative in context', Journal of Vocational Behavior, 54, pp. 279-295. doi: 10.1080/13636829700200012.

Daerga, L., Edin-Liljegren, A. and Sjölander, P. (2008) 'Quality of life in relation to physical, psychosocial and socioeconomic conditions among reindeer-herding Sami', International Journal of Circumpolar Health, 67(1), pp. 10-28. doi: 10.3402/ ijch.v67i1.18223.

Evans, K. M. (2018/1998) Shaping futures: learning for competence and citizenship. New York, NY: Routledge.

Ferry, N. M. (2006) 'Factors influencing career choices of adolescents and young adults in rural Pennsylvania', Journal of Extension, 44(3), pp. 205-212. doi: 10.5367/ ihe.2015.0253.

Fizer, D. (2013) Factors affecting career choices of college students enrolled in agriculture. Master's thesis, University of Tennessee, Martin. Available at: https://www. utm.edu/departments/msanr/_pdfs/Fizer_Research_Project_Final.pdf (Accessed: 18 February 2021).

Fleming, A. E., Petheram, L., and Stacey, N. (2015) 'Australian Indigenous women's seafood harvesting practices and prospects for integrating aquaculture', Journal of Enterprising Communities: People and Places in the Global Economy, 9(2), pp. 156-181. doi: 10.1108/JEC-08-2014-0013.

Frangou, S.-M. and Keskitalo, P. (2020) Substantiating vocational competency identity in reindeer herding studies. Master's thesis, Oulu University of Applied Sciences. Available at: https://www.theseus.fi/handle/10024/340624 (Accessed: 18 February 2019).

Furberg, M., Evengård, B. and Nilsson, M. (2011) 'Facing the limit of resilience: Perceptions of climate change among reindeer herding Sami in Sweden', Global Health Action, 4(1), p. 8417. doi: 10.3402/gha.v4i0.8417.

Gillan, K., Mellor, S., and Krakouer, J. (2017) The case for urgency: Advocating for Indigenous voice in education. Camberwell, Victoria: Australian Council for Educational Research. Available at: https://research.acer.edu.au/cgi/viewcontent. cgi?article $=1027 \&$ context $=$ aer (Accessed: February 18 2021).

Haley, S. and Fisher, D. (2014) 'Indigenous employment, training and retention: Successes and challenge in Red Dog Mine', in Gilberthorpe, E. and Hilson, G. (eds.) Natural resource extraction and Indigenous livelihoods: development and challenges in the era of globalization. London: Routledge, pp. 11-35.

Heikkinen, H. (2006) 'Neo-entrepreneurship as an adaptation model of reindeer herding in Finland', Nomadic Peoples, 10(2), pp. 187-208. doi: 10.3167/np.2006. 100211.

Heleniak, T. (2020) 'The future of the Arctic populations', Polar Geography. doi: 10.1080/1088937X.2019.1707316.

Hoolachan, J., McKee, K., Moore, T., and Soaita, A. M. (2017) "Generation rent" and the ability to "settle down": Economic and geographical variation in young people's housing transitions', Journal of Youth Studies, 20(1), pp. 63-78. doi: 10.1080/13676261.2016.1184241.

Indigenous Peoples Forum at IFAD. (2017) Synthesis of deliberations. Available at: https://www.ifad.org/documents/36783902/40298813/Synthesis+of+Deliberations_ 


\section{Tanja Joona and Pigga Keskitalo}

Third+Global+Meeting+Indigenous+Peoples+Forum+at+IFAD.pdf/9b62de47b5f6-4aaa-9e0f-40df3a90b338 (Accessed 17 February 2021).

International Centre of Reindeer Herding. (2015) Eallin: reindeer herding youth full report. Kautokeino. Available at: https://www.scribd.com/document/262802467/ Eallin-Reindeer-Herding-Youth-Full-Report (Accessed: February 18 2021).

Jernsletten, J.-L. L. and Klokov, K. (2002) Sustainable reindeer husbandry. University of Tromsø. Centre for Saami Studies. Available at: http://www.reindeer-husbandry. uit.no/online/Final_Report/final_report.pdf (Accessed: February 17 2021).

Joks, S. (2005) 'Boazosámi nissonolbmot - oaidnemeahttun geađgejuolgi', Sámi dieđalaš áigečála, 1, pp. 39-56.

Jones, G. (2002) The youth divide: diverging paths to adulthood. Bristol: Joseph Rowntree Foundation. Available at: http://www.bristol.ac.uk/poverty/ESRCJSPS/ downloads/research/uk/3\%20UK-Poverty, $\% 20$ Inequality $\% 20$ and $\% 20$ Social $\% 20$ Exclusion $\% 20$ (the $\% 20$ Youth) $/$ Book $\% 20$ (UK $\% 20$ Youth) $/$ Jones- $\% 20$ The $\% 20$ Youth $\% 20$ Divide $\% 20$ Diverging $\% 20$ paths $\% 20$ to $\% 20$ adulthood.pdf (Accessed: February 18 2021).

Joona, T. (2018) Everyday life in the Arctic. In a blog: Polar prediction matters. Available at: https://blogs.helmholtz.de/polarpredictionmatters/ (Accessed: February 18 2021).

Kaiser, N. (2011) Mental health problems among the Swedish reindeer-herding Sami population: In perspective of intersectionality, organisational culture and acculturation. Umeå: Umeå University, Faculty of Medicine, Department of Clinical Sciences, Psychiatry.

Kaiser, N., Näckter, S., Karlsson, M. and Salander Renberg, E. (2015) 'Experiences of being a young female Sami reindeer herder: A qualitative study from the perspective of mental health and intersectionality', Journal of Northern Studies, 9(2), pp. 55-72. Available at: http://urn.kb.se/resolve?urn=urn:nbn:se:umu:diva-119918 (Accessed: February 18 2021).

Kaiser, N., Ruong, T. and Salander Renberg, E. (2013) 'Experiences of being a young male Sami reindeer herder: a qualitative study in perspective of mental health', International Journal of Circumpolar Health, 72(1). doi: 10.3402/ijch.v72i0.20926.

Kaiser, N., Sjölander Liljegren, A. E., Jacobsson, L. and Salander Renberg, E. (2010) 'Depression and anxiety in the reindeer-herding Sami population of Sweden', International Journal of Circumpolar Health, 69(4), pp. 383-393. doi: 10.3402/ijch. v69i4.17674.

Karlsdottir, A. (2015) 'Nordic youth and future visions', in Karlsdóttir, A. and Jungsberg, L. (eds.) Nordic Arctic youth future perspectives. Stockholm: Nordregio, pp. 65-70. Available at: http://norden.diva-portal.org/smash/get/diva2:1128959/ FULLTEXT01.pdf (Accessed: February 19 2021).

Karlsdottìr, A. and Jungsberg, L. (2015) Youth perspectives on their future in the Nordic Arctic. Nordregio Policy Brief, pp. 1-4. Available at: https://www.divaportal.org/smash/get/diva2:843858/FULLTEXT01.pdf (Accessed: February 18 2021).

Keskitalo, P. (2019) 'Nomadic narratives of Sámi people's migration in historic and modern times', in Uusiautti, S. and Yeasmin, N. (eds.) Human migration in the Arctic: the past, present, and future. Singapore: Palgrave Macmillan, pp. 31-65.

Keskitalo, P., Frangou, S.-M., and Chohan, I. (2020) 'Educational design research in collaboration with students: developing a reindeer herding study programme and a model of vocational Sámi pedagogy', Education in the North, 27(1), pp. 58-77. doi: $10.26203 / 3 \mathrm{jtv}-9 \mathrm{~g} 81$.

Kokkinen, A. (2012) On Finland's economic growth and convergence with Sweden and the EU15 in the 20th century (Research Reports 258). Helsinki: Statistics Finland. 
Kumpula, J. (2012) 'Ilmastonmuutos ja poronhoito', in Ruuhela, R. (ed.) Miten väistämättömään ilmastonmuutokseen voidaan sopeutua? Yhteenveto suomalaisesta sopeutumistutkimuksesta eri toimialoilla'. Maa- ja metsätalousministeriön julkaisuja, 6, 2011. Helsinki, Maa- ja metsätalousministeriö, pp. 56-60.

Laitala, M. and Puuronen, V. (2015) 'A day in my life as a 35-year-old', in Karlsdóttir, A. and Jungsberg, L. (eds.) Nordic Arctic youth future perspectives. Stockholm: Nordic Arctic Youth Future Perspectives, pp. 27-35. Available at: http://norden. diva-portal.org/smash/get/diva2:1128959/FULLTEXT01.pdf (Accessed: 19 February 2021).

Lépy, E., Heikkinen, H. I., Komu, T., and Sarkki, S. (2018) 'Participatory meaning making of environmental and cultural changes in reindeer herding in the northernmost border area of Sweden and Finland', International Journal of Business and Globalisation, 20(2). doi: 10.1504/IJBG.2018.089868.

Lindqvist, J. (2009) 'Reindeer herding: a traditional indigenous livelihood', Macquarie Journal of International and Comparative Environmental Law, 6(1), pp. 83-127.

Luke. (2016) Porotalous [Reindeer husbandry]. Available at: https://www.luke.fi/ tietoa-luonnonvaroista/maatalous-ja-maaseutu/porotalous/ (Accessed: February 19 2021).

Mbunda, Fr D. (1983) 'Cultural values, tradition and modernity', in UNESCO (ed.) Problems of culture and cultural values in the contemporary world. Paris: UNESCO, pp. 13-21. Available at:https://unesdoc.unesco.org/in/documentViewer.xhtml?v=2. 1.196\&id=p::usmarcdef_0000054681\&file=/in/rest/annotationSVC/ DownloadWatermarkedAttachment/attach_import_97ba803b-3251-4a9b-ae6e$860 \mathrm{a} 8 \mathrm{~b} 2 \mathrm{a} 888 \mathrm{~d} \% 3 \mathrm{~F} \_\% 3 \mathrm{D} 054681$ engo.pdf\&locale $=$ en $\&$ multi $=$ true $\&$ ark $=$ / ark:/48223/pf0000054681/PDF/054681engo.pdf\#\%5B $\% 7 \mathrm{~B} \% 22$ num $\% 22 \% 3 \mathrm{~A} 43 \% 2$ $\mathrm{C} \% 22$ gen $\% 22 \% 3 \mathrm{~A} 0 \% 7 \mathrm{D} \% 2 \mathrm{C} \% 7 \mathrm{~B} \% 22$ name $\% 22 \% 3 \mathrm{~A} \% 22 \mathrm{XYZ} \% 22 \% 7 \mathrm{D} \% 2 \mathrm{C}-$ 229\%2C856\%2C0\%5D (Accessed: December 212020 ).

Merikivi, J., Myllyniemi, S., and Salasuo, M. (eds.) (2016) Lasten ja nuorten vapaaaikatutkimus 2016 mediasta ja liikunnasta. Media hanskassa [Leisure survey of children and young people 2016 on media and exercise. Media in a glove]. Helsinki: Nuorisotutkimusseura. Available at: https://issuu.com/tietoanuorista/docs/lasten_ ja_nuorten_vapaa-aikatutkimu (Accessed: December 23 2021).

Miller, C. (2005) Aspects of training that meet Indigenous Australians' aspirations: A systematic review of research. Adelaide, Australia: National Centre for Vocational Education Research. Available at: https://files.eric.ed.gov/fulltext/ED493924.pdf (Accessed: November 25 2020).

Nieminen-Sundell, R. (2011) Maisema on, työ puиttuu. Helsinki: Sitra. Available at: https://media.sitra.fi/2017/02/27172821/Maisema_on_tyC3B6_puuttuu-2.pdf (Accessed: November 23 2020).

Nuorisolaki, 1285/2016. Finlex. Available at: https://www.finlex.fi/fi/laki/alkup/2016/ 20161285 (Accessed: July 15 2021).

Nymand Larsen, J., Fondahl, G., and Schweitzer, P. (2010). Arctic social indicators: a follow-up to the Arctic Human Development Report. Copenhagen: Nordic Council of Ministers. Available at: http://norden.diva-portal.org/smash/get/diva2:789051/ FULLTEXT02.pdf (Accessed: July 15 2021).

Öhman, M.-B. (2015) 'Sámi youth struggling for rights and recognition', in Karlsdóttir, A. and Jungsberg, L. (eds.) Nordic Arctic youth future perspectives. Stockholm: Nordic Arctic Youth Future Perspectives, pp. 47-54. Available at: http://norden. diva-portal.org/smash/get/diva2:1128959/FULLTEXT01.pdf (Accessed: October 29 2020). 
Oinas, P. (2018) Poroperheiden sosiaalinen ja taloudellinen selviytyminen elinkeinollisessa ja yhteisöllisessä murroksessa [Social and economic survival of reindeer families in the economic and communal transformation]. University of Lapland. Department of Social Sciences. Available at: https://lauda.ulapland.fi/bitstream/ handle/10024/63156/Oinas.Pirjo.pdf?sequence=1\&isAllowed=y (Accessed: October 29 2020).

Ojala, J., Eloranta, J. and Jalava, J. (eds.) (2006) The road to prosperity: an economic history of Finland. Helsinki: Suomalaisen Kirjallisuuden Seura.

Ollila, A. (2014) Reindeer blog. Rovaniemi: Paliskuntain yhdistys. Available at: https:// paliskuntainyhdistys.blogspot.com/2014/08/ (Accessed: October 23 2020).

Ollila, A. (2019) Poronhoitoa nyt ja tulevaisuudessa [Reindeer husbandry now and in the future]. Web log. Rovaniemi: Paliskuntain yhdistys. Available at: https://poromieslehti.blogspot.com/2019/12/poronhoitoa-nyt-ja-tulevaisuudessa.html (Accessed: October 23 2020).

Omma, L. M., Holmgren, L. E., and Jacobsson, L. H. (2011) 'Being a young Sami in Sweden: living conditions, identity and life satisfaction', Journal of Northern Studies, 5(1), pp. 9-28.

Pekkarinen, A. (2006) 'Changes in reindeer herding work and their effect on occupational accidents', International Journal of Circumpolar Health, 65(4), pp. 357-364. doi: 10.3402/ijch.v65i4.18125.

Pirttilä, I.-A. (2020) 18 years old reindeer herder girl Iida-Aletta and her Arctic life. Visit Lapland. Available at: https://www.ourlapland.fi/reindeer-herder-girl-iidaaletta-from-lapland (Accessed: December 23 2020).

Pogodaev, M. and Oskal, A. (2015) Youth. The future of reindeer herding peoples. Documentation. Arctic Council. Available at: http://reindeerherding.org/wpcontent/uploads/2015/01/ICRH-0115-01_Voice_of_Reindeer_Herding_Youth_ v07.00.compressed.pdf.

Povoroznyuk, O., Habeck, J., and Vaté, V. (2010) 'Introduction: on the definition, theory and practice of gender shift in the north of Russia', Anthropology of East Europe Review, 28(2), pp. 1-37.

Rasmus, S., Kivinen, S., Bavay, M., \& Heiskanen, J. (2016). Local and regional variability in snow conditions in northern Finland: a reindeer herding perspective, Ambio, 45(4), 398-414.

Rasmus, S., Turunen, M., Luomaranta, A., Kivinen, S., Jylhä, K., and Räihä, J. (2020) 'Climate change and reindeer management in Finland: Co-analysis of practitioner knowledge and meteorological data for better adaptation', Science of the Total Environment, 710. doi: 10.1016/j.scitotenv.2019.136229.

Rasmussen, R. O. (2009) 'Gender and generation: perspectives on ongoing social and environmental changes in the Arctic', Signs, 34(3), pp. 524-532. doi: https://doi. org/10.1086/593342.

Rehtonen, T. (2019) Nuoria naisia ja vanhoja miehiä [Young women and old men]. Poromieslehti. Availabe at: https://poromieslehti.blogspot.com/2019/11/nuorianaisia-ja-vanhoja-miehia.html (Accessed: August 20 2020).

Reindeer Herders' Association. (2015) Reindeer herding cooperatives. Rovaniemi. Available at: https://paliskunnat.fi/reindeer/reindeer-herding/cooperatives/ (Accessed: 20 August 2020).

Reindeer Herders' Association. (2019) Miesten ja naisten kehityksen määrä poronomistajissa [The rate of development of men and women in reindeer herders]. Rovaniemi. Available at: https://paliskunnat.fi/py/materiaalit/tilastot/poronomistajat/miehia_ja_naisia_poronomistajissa_1990_2018/ (Accessed: August 20 2020). 
Reindeer Herders' Association. (2020a) Poro [Reindeer]. Rovaniemi. Available at: https://paliskunnat.fi/py/wp-content/uploads/2020/09/Reindeer_2020.pdf (Accessed: August 18 2020).

Reindeer Herders' Association. (2020b) Development of reindeer herding. Rovaniemi. Available at: https://paliskunnat.fi/reindeer/reindeer-herding/history/ (Accessed: June 29 2020).

Reindeer Herders' Association. (2020c) Poronuoret [Reindeer youth]. Rovaniemi. Available at: https://paliskunnat.fi/poro/poronhoito/poromiehen-ammatti/poronuoret/ (Accessed: August 20 2020).

Reinert E. S., Aslaksen, I. Eira, I. M. G., Mathiesen, S. D., Reinert, H., and Turi, E. I. (2009) 'Adapting to climate change in Sámi reindeer herding: the nation-state as problem and solution', in Adger, W. N., Lorenzoni, I. and O'Brien, K. L. (eds.) Adapting to climate change: Thresholds, values, governance. Cambridge: Cambridge University Press, pp. 417-432.

Reiter, C. and Lutz, W. (2019) 'Survival and years of good life in Finland in the very long run', Finnish Yearbook of Population Research, 54, pp. 1-27.

Sámi Education Institute. (2020) Reindeer husbandry entrepreneurship: vocational qualification in nature and environment. Inari. Available at: http://www.sogsakk. fi/en/Applicants/Educational-Training-Programs/Reindeer-HusbandryEntrepreneurship (Accessed: August 20 2020).

Sarkki, S., Komu, T. Heikkinen, H. I., Acosta García, N., Lépy, É., and Herva, V.-P. (2016) 'Applying a synthetic approach to the resilience of Finnish reindeer herding as a changing livelihood', Ecology and Society, 21(4). Available at: https://www. jstor.org/stable/26270038 (Accessed: November 20 2020).

Schindler, D. L. (1997) 'Redefining tradition and renegotiating ethnicity in native Russia', Arctic Anthropology, 34(1), pp. 194-211.

Ssorin-Chaikov, N. V. (2003). The social life of the state in subarctic Siberia. Stanford: Stanford University Press.

Statistics Finland. (2019) Finland among the best in the world. Available at: http:// www.stat.fi/tup/satavuotias-suomi/suomi-maailmankarjessa_en.html (Accessed: August 20 2020).

Super, D. E., Savickas, M. L., and Super, C. M. (1996) 'The life-span approach to careers', Career Choice and Development, 3, pp. 121-178.

Tveraa, T., Stien, A., Bårdsen, B.-J., and Fauchald, P. (2013) 'Population densities, vegetation green-up, and plant productivity: impacts on reproductive success and juvenile body mass in reindeer', PLOS ONE, 8(2). doi: 10.1371/journal. pone. 0056450 .

Uboni, A. et al. (2016) 'Long-term trends and role of climate in the population dynamics of Eurasian reindeer', PLoS ONE, 11(6). doi: 10.1371/journal. pone. 0158359 .

Ulturgasheva, O. (2012a) Narrating the future in Siberia: childhood, adolescence and autobiography among Eveny. Oxford: Berghahn Books. Available at: http://www. berghahnbooks.com/title.php?rowtag=UlturgashevaNarrating (Accessed: November 20 2020).

Ulturgasheva, O. (2012b) 'Navigating international, interdisciplinary, and Indigenous collaborative inquiry: Phase 1 in the circumpolar Indigenous pathways to adulthood project', Journal Community Engagem Scholarsh, 4(1), pp. 50-59. Available at: https://digitalcommons.northgeorgia.edu/jces/vol4/iss1/6. 
Ulturgasheva, O. (2014) 'Attaining khinem: Challenges, coping strategies and resilience among eveny adolescents in northeastern Siberia', Transcultural Psychiatry, 51(5), pp. 632-650. doi: 10.1177/1363461514546246.

Ulturgasheva, O. (2015) 'Collapsing the distance: Indigenous-youth engagement in a circumpolar study of youth resilience', Arctic Anthropology, 52(1), pp. 60-70. doi: 10.3368/aa.52.1.60.

Ulturgasheva, O., Rasmus, S., Wexler, L., Nystad, K. and Kral, M. (2014) 'Arctic indigenous youth resilience and vulnerability: comparative analysis of adolescent experiences across five circumpolar communities', Transcultural Psychiatry, 51(5), pp. 735-756. doi: 10.1177/1363461514547120.

United Nations. (2009) State of the world's Indigenous peoples. New York, NY: Department of Economic and Social Affairs Division for Social Policy and Development Secretariat of the Permanent Forum on Indigenous Issues. Available at: https://www.un.org/esa/socdev/unpfii/documents/SOWIP/en/SOWIP_web.pdf (Accessed: October 29 2020).

Veijola, S. and Strauss-Mazzullo, H. (2018) 'Tourism at the crossroads of contesting paradigm of Arctic development', in Finger, M. and Heinonen, L. (eds.) The Global Arctic Handbook. Cham: Springer, pp. 63-81.

Vitebsky, P. (2010) 'From materfamilias to dinner-lady: The administrative destruction of the reindeer herder's family life', The Anthropology of East Europe Review, 28 , pp. $38-50$.

Voutilainen, M. (2016) Poverty, inequality and the Finnish 1860s famine. Doctoral dissertation, University of Jyväskylä. Available at: https://jyx.jyu.fi/bitstream/ handle/123456789/49598/978-951-39-6627-0_vaitos13052016.pdf?sequence=1.

Vuojala-Magga, T. and Turunen, M. T. (2015) 'Sámi reindeer herders' perspective on herbivory of subarctic mountain birch forests by geometrid moths and reindeer: a case study from northernmost Finland', Springerplus, 4(134). Available at: https:// www.ncbi.nlm.nih.gov/pmc/articles/PMC4374085/ (Accessed: November 14 2020).

Vuojala-Magga, T. et al. (2011) 'Resonance strategies of Sámi reindeer herders in northernmost Finland during climatically extreme years', Arctic, 64(2), pp. 227241. Available at: www.jstor.org/stable/23025696 (Accessed: August 20 2020).

Wennstedt, E. B. (2002) 'Reindeer herding and history in the mountains of Southern Sapmi', Current Swedish Archaeology, 10, pp. 115-136. Available at:http://www. arkeologiskasamfundet.se/csa/Dokument/Volumes/csa_vol_10_2002/csa_ vol_10_2002_s115-136_wennstedt-edvinger.pdf (Accessed: November 20 2020).

West, P., Sweeting, H., and Young, R. (2010) 'Transition matters: pupils' experiences of the primary-secondary school transition in the West of Scotland and consequences for well-being', Research Papers in Education, 25(1), pp. 21-50. doi: 10.1080/02671520802308677.

\section{Appendix}

Interview Questions

Age:

Gender:

Education:

What is your first memory related to reindeer herding?

Is reindeer herding practised in your family? Who is the most active member? 
Do you know how long reindeer herding has been practised in your family? How do you participate in reindeer herding and related work?

What is the most interesting (the most fun) thing when you're involved in reindeer herding?

What are your future plans (after completing school)?

Do you want to study more?

Would you like to continue in reindeer herding? How? Would it be possible to combine different occupations?

Do you want to continue living where you live right now, or do you want to explore the world a little bit? Study/work somewhere else?

What do you think about the future of reindeer herding?

What do you think about climate change? Do you think it will affect reindeer herding?

What do you think about reindeer herding in general? Do you think that reindeer herding will bring you income in the future?

Interview questions for guardians:

What do you think of the future of reindeer herding related to your children?

Can you describe the different kinds of tasks that the family does? 